\title{
FROM THE VIOLENT "BLACK BUCK" STEREOTYPE TO THE "BLACK HERO": REPRESENTATIONS OF AFRICAN AMERICANS AND BLACK MASCULINITY IN AMERICAN CINEMA
}

\author{
UDC 316.647.8:791.43(73)
}

\author{
Ana Kocić \\ University of Niš, Faculty of Philosophy, Niš, Serbia
}

\begin{abstract}
The main purpose of this paper is to examine the representation of black masculinity in four popular Hollywood movies. In the first part of the paper, the key terms and analytical points are developed, based on the relevant literature from the fields of cultural, film and media studies, African American studies and black feminism. A special emphasis is placed on the transition from a stereotype of the "Black Buck", a common on-screen representation of a violent, vengeful, highly sexual black male to the "Black Hero", created in the Blaxploitation movies and further developed in more recent movies. The four movies that are closely analyzed are Sergio Corbucci's Django from 1966, Gordon Parks's Shaft from 1971 and their contemporary adaptations, Shaft (2000), directed by John Singleton and Django Unchained (2012), directed by Quentin Tarantino. One of the tasks of the research is to examine how the stereotype of a violent black thug has been deconstructed and modified in more recent movies to usher the "Black Hero" character.
\end{abstract}

Key words: African American studies, black masculinity, film studies, representation, stereotype

\section{INTRODUCTION}

Representation of African Americans in Hollywood movies both in terms of their onscreen representations and in terms of their importance for the Hollywood industry has proved to be a highly divisive and controversial issue. This paper is an attempt to make a modest contribution to the on-going debate. When it comes to the common depictions of African Americans in films, several trends can be observed: from a very strictlydelineated and decisively racist portrayals in the first half of the $20^{\text {th }}$ century, followed by

Submitted November $13^{\text {th }} 2016$, accepted for publication March $27^{\text {th }}, 2017$

Corresponding author: Ana Kocić

University of Niš, Faculty of Philosophy, Niš, Serbia

E-mail: anakocic@hotmail.com 
various phases of more or less subtle stereotyping, a vast majority of on-screen portrayals have been unfavorable and deprecating for African Americans. The 1970s and the Blaxploitation period brought more diverse portrayals of African Americans which developed from previous stereotypes; thus, paving the way for the biracial buddy movies and authentic "Black Heroes" (Guerrero 1993: 37).

The paper deals with representations of African Americans in four popular (Hollywood) movies of the $20^{\text {th }}$ and $21^{\text {st }}$ centuries with a special emphasis on the representation of black masculinity, the role and purpose of violence in those representations and the dependence of representation on the socio-historical context. The focus is on the transition from the stereotypical "Black Buck" character, a representation of a violent and bestial African American to more positive representations and a character of the "Black Hero". The first part of the paper draws upon definitions of masculinity, representations of black masculinity, violence as a component of (black) masculinity and common stereotypes of African Americans in movies by well-known cultural, media and film theorists in order to establish a valid theoretical framework for the research. The second part of the paper consists of the analyses of four widely-known movies, shot between 1966 and 2012, which center on the theme of violence and feature prominent black and/or macho characters: Django and Shaft. The aim is to examine how representations of African Americans in popular movies have varied over time and what directions those variations took. It is noticeable that many features that were stereotypically ascribed to black male characters have been deconstructed and subverted in a more recent period, thus paving the way for the genuine "Black Hero". While it is true that these movies can be analyzed from multiple perspectives, whether according to their genre, or the period in which they were filmed, we have opted to single out one aspect: that of male heroes and their traits and representations.

\section{2. (BLACK) MASCULINITY AND VIOLENCE}

Anthony Lemelle (2010: 3) defines masculinity as "the socially constructed characteristics that society expects for the male sex", meaning that the features generally considered to be masculine depend on the cultural patterns of any given society and are perpetuated as such through high and popular culture. A similar view is expressed by Sean Nixon (1997: 301) who claims that there is no "ideal masculinity"; rather, it is a fluid notion that changes depending on the meanings that are highlighted as important at any given historical moment. Nixon views masculinity as a mode of representation, prevalent in the media and various cultural texts (Storey 2012: 163-4). Furthermore, the hegemonic or dominant masculinity often includes only the notion of white heterosexual masculinity, which is set as a standard that men are supposed to live up to (Ibid.). When it comes to the representation of masculinity, violence is very often emphasized as one of its major components. Analyzing violent white masculinity in advertising in the recent period (2000-2010), Katz (2011: 262-3) traces the roots of such modes of representation to the 1970s and 1980s and the socio-economic insecurity of the working class white males: the argument is that men tend to establish their position in the society which does not offer them economic security and validation by committing acts of violence. Furthermore, Katz (Ibid.) claims that such images of aggressive and violent masculinity were promoted through the "violent male icons", as well as "military and sports symbolism"; thus linking masculinity with weapons and physical prowess. On a similar note, Costera Meijer and 
Van Zoonen (2002: 326-40) argue that two vital aspects in the media construction of masculinity in the late $20^{\text {th }}$ century are a powerful male body and violence, i.e. sheer physical strength and its application in order to secure dominance.

A powerful, strong body and a proclivity to violence have also often been connected to the representation of black masculinity, which, in turn, has often been constructed as an alternative to the dominant (and desirable) white masculinity. bell hooks (2004: 13) mentions the alternatives to the dominant white masculinity embodied in the figures of black artists, musicians and sportsmen from the 1960s on. Those alternatives can be both desirable - as is the case with the representations of black men as a class of physically impressive "super-males", and undesirable - in cases in which African Americans are represented as violent and aggressive (hooks 1992: 36). On one hand, the promoted image of African American men in American culture has been that of "cool, strong black rebels" as a contrast to a "weak and soft white boy" (Ibid.). On the other hand, hooks draws attention to the fact that violent, even psychopathic behavior has often been ascribed to black males, which contributed to the racist depictions of African American men as a subhuman species, deprived of empathy and human(e) feelings (Ibid.). hooks also mentions the black body with its ascribed (over)sexuality, driven exclusively by the pleasure principle, which is represented as a threatening Other that may destroy with excessive pleasure (Ibid., p. 22). Lemelle (2010: 2, 47) notices a similar trend in the representation of black masculinity in popular media, the phenomenon which he traces through the history of the Western culture from the $17^{\text {th }}$ century and Shakespeare's The Tempest. He points out that African Americans are often represented as either hypermasculine and hypersexual beings or socially feminized, passive and helpless (Ibid.). The purpose of this strategy of stereotyping is to perpetuate the subordinate social position of African Americans in the U.S. society (Ibid. p. 36). On the negative end of the representation spectrum, a typical portrayal of African Americans on screen often includes their association with criminal activities (Tasker 2002: 36). Henry (2004: 119) makes a connection between the prominence of hip-hop and rap cultures of the 1990s and the promotion of violent black masculinity: he identifies a culturally prominent type of black masculinity that is "defined mainly by an urban aesthetic, a nihilistic attitude and an aggressive posturing". This kind of portrayal has its roots in the movies of the Blaxploitation period.

As we mentioned above, the representation of masculinity is characterized by fluidity and may also be the site of contest between various meanings and thus a potential means of subversion of stereotypes. Hall (1997: 270-5) calls these strategies trans-coding, i.e. changing the originally intended meaning of a stereotype by reversing it, or enforcing positive images, or, "contesting it from within" so as to undermine its meaning and make it work against itself. As opposed to the authors cited above, Hall emphasizes the importance of Blaxploitation movies for introducing African Americans into the U.S. cultural mainstream (Ibid.). In a similar vein, instead of focusing on the reductive quality of stereotyping, Tasker (2002: 35-6, 74-9) stresses the importance of a strong black body image, especially in action movies from the 1970s onwards, both in terms of securing visibility and roles for the African American actors, as well as making the black body a means of telling "powerful stories of subjection and resistance". According to her, the images of strong and successful African American athletes in sports arenas were transferred onto movie screens thus opening new possibilities of (positive) representation. 


\subsection{Representations of African Americans in Hollywood Movies}

In his seminal study of the common stereotypical representations of African Americans in Hollywood cinema, Donald Bogle (2016: 1-15) identified five common categories of stereotypes, one of which is particularly important for this paper: that of "the Black Buck", a character of a violent young black male. The "Black Buck" type, which developed from its minstrel show precursors, was first introduced on screen in 1915 in D.W. Griffith's Birth of a Nation, through the character of Gus, a former slave who attempts to rape Flora Cameron, a white woman, and ultimately drives her to death. This stereotypical representation has its roots in the racist doctrine of white supremacy, according to which those of African origin were marked as brutal savages, both mentally and physically inferior (facial features of African Americans were deemed ugly and ape-like) to the white population; whereas, the very notion of miscegenation was considered abominable and unthinkable (Fredrickson 1987: 49). According to the logic of white supremacists, the alleged violent, beastly and subhuman presence of African Americans threatens the "ideal" white community, most commonly embodied in a body of a beautiful, fragile white woman. Evolving from the Gus character, the features of "the Black Buck" type usually include violence, rudeness, lechery and disrespect for any kind of (white) authority (Bogle 2016: 7-14, 198-219).

The stereotype of a violent black thug was modified in the 1970s evolving into a "black superspade", known for the "cool-as-a-cucumber" attitude and sexual prowess (Guerrero 1993: 69). This stereotypical image was promoted in the period of Blaxploitation, roughly between 1969 and 1974, when a series of movies with black casts was filmed focusing on black themes and contexts (Ibid.) with the purpose of appealing to the growing black audience. As Ed Guerrero (1993: 110) points out, Blaxploitation movies developed according to a preset formula: "violent expressions of black manhood or womanhood, and a black-white confrontation that ends with the oppressed black coming out spectacularly victorious". Audiences (both black and white) were thus encouraged to side with a sexually powerful, "cool" rebel, who defies any kind of authority and manages to win on his own (frequently violent) terms. Although representations of African American characters were still reductive and with an agenda directed exclusively towards a financial success, one important contribution of the movies from this period was the fact that these characters were in the main roles, heroes of the movies, with a celebrity status. Furthermore, with the introduction of a new "Black Hero", the Blaxploitation period movies represented white society as prejudiced and corrupted, and a metaphor for any kind of oppressive system (Novotny 2008: 18-20).

The popularity of Blaxploitation movies quickly faded, but nonetheless, an important space for African American actors and actresses and for more diverse on-screen portrayals was opened in mainstream Hollywood cinema. While it is certainly true that many of the film representations were unfavorable, patronizing and generally racist, it should also be observed that more and more African American actresses and actors obtained opportunities for more important and better paid and appreciated roles ${ }^{1}$. The message from Hollywood studios seemed to be that there is room for African Americans in the mainstream cinema, as long as they play the prescribed roles. However, after the Blaxploitation period, the focus

\footnotetext{
${ }^{1}$ Thus, for example, Sidney Poitier, (in)famous for his portrayals of the so-called "ebony saints", was the first African American man to win an Oscar in 1964 and a Hollywood star status. The first black woman to win an Oscar was Hattie McDaniel for her portrayal of a stereotypical Mammy character in Victor Fleming's 1939 Gone with the Wind.
} 
shifted to black themes and characters, thus opening space for comedians such as Eddie Murphy and Whoopi Goldberg and their success in comedy and the "biracial buddy" movies in the 1980s (Guerrero 1993: 133). Even though it can be argued that in the 1980s and 1990s African American actors and actresses were somewhat limited to either comedies or the roles of faithful sidekicks to white leads in white surroundings (Ibid. p. 72, 126), it still cannot be denied that the number of black stars and lead roles grew steadily over the years. What is more, this paved the way for African American directors and their resistance to discriminatory conventions and modes of representation, both as independent filmmakers or parts of the mainstream Hollywood (Ibid, pp. 179-80). It is also important to mention that some white directors also attempted to represent African Americans on screen with more nuance and outside the stereotypical roles. In the following sections, we will provide the illustrations for some of the above-mentioned claims by analyzing the representation of four iconic male movie characters exhibiting some traits of violent masculinity.

\section{TRacing the DeVElopment of THE "Black HeRo” CHARACTER}

As previously described, the research hypothesis of the paper, that the character of the "Black Hero" developed from the characters of the "(White) Hero" and the "Black Buck" will be examined by analyzing four popular (Hollywood) movies which include: Sergio Corbucci's Django from 1966, Gordon Parks's Shaft from 1971 and their contemporary adaptations, Shaft (2000), directed by John Singleton and Django Unchained (2012), directed by Quentin Tarantino. Both original movies can be considered important landmarks in the American cinema in terms of representation of African Americans, introducing the prototype of a hero and the use of violence. Both adaptations remodeled and re-worked the characters from the original movies, adjusting those representations to their contemporary contexts.

One of the major reasons for choosing these movies is the fact that all of them achieved a high level of popularity in terms of audience, critical response, awards and the somewhat iconic status of their main heroes. Sergio Corbucci's Django is one of the most famous spaghetti westerns, critically acclaimed and best known for its legacy and the influence it had on similar projects. In Howard Hughes'(2004: xxi-xxii) monograph on the development of spaghetti westerns, several critics include Django among the ten most successful movies of this genre, although when it first appeared, it was considered to be extremely violent and was even banned in some countries. Although this movie does not feature any prominent African American characters, it is mentioned in the context of its iconic status and the inspiration it provided for Tarantino later. Gordon Parks's Shaft is a famous example of the Blaxploitation era which produced what would later become a typical African American character - cool, sexually powerful "badass with an attitude" (Henry 2004: 116). It also made Richard Roundtree, its lead actor, a Hollywood celebrity and took an important place in the Hollywood cinema history and popular culture, especially because of its theme song which won an Oscar for composer Isaac Hayes in 1971. John Singleton's Shaft, which, according to its director is a sequel to the original movie, ushered in the period of the cinematic re-examination of the Blaxploitation period. It re-assessed the representations of African Americans and introduced some new themes, relevant for the period in which it was filmed. With Samuel L. Jackson, an alreadyestablished African American Hollywood star as a male lead, this movie drew a lot of 
attention from audiences, and despite its not-so-favorable critiques and a lack of sequels, still managed to earn a decent amount of money for the Hollywood studios (Aldous 2015: 215). Quentin Tarantino's Django Unchained is an extremely popular Hollywood homage piece with references to the other three movies. It redefined, reconsidered and remade popular stereotypes, using graphic violence as one of its major components as is often the case with Tarantino's movies. This movie seems to have initiated a wave of new modes of representation of African Americans and a Hollywood industry turn towards mass production of the movies about African American history, many of which were critically acclaimed, with large audiences and numerous awards (for example, Steve McQueen's 12 Years a Slave from 2013, Lee Daniels' The Butler from 2013, and Ava DuVernay's Selma from 2014). This "new wave" of movies re-examining American history coincided with the election of the first African American president of the USA and can thus be considered from the point of being socially and politically conditioned (Bogle 2016: 464).

All of the movies, in their own ways, genres and modes, tackle the issue of stereotypical representations, and deal with the racist and/or discriminatory ideologies.

\subsection{The ideal "White Macho" - Django}

Sergio Corbucci's Django, filmed in 1966 belongs to the so-called spaghetti western genre which included a number of very popular movies mostly produced in Italy in the 1960s inspired by American westerns (Hughes 2004: vii-x).

In Corbucci's movie the main character is an outsider, a Civil War veteran who finds himself in the middle of a conflict of two opposing currents, neither of which he sides with. Even though Corbucci's Django is white, and, strictly speaking, does not belong to a minority group, racial tension is accentuated with the appearance of Major Jackson's followers who are clearly the KKK members and their hostility towards the Mexicans who are represented as undesired Others. The behavior of Major Jackson's men towards Mexicans proves that racist prejudices need not be aimed at one particular group, but are characteristic of the system based on violence and the predatory logic of the survival of the fittest, which often also means the cruelest. Django's position is that of a lone vigilante, who only occasionally chooses to interfere, most often to protect those who are weaker and helpless. Although he once fought on the side of the Union, it is suggested that he is disillusioned, and when the movie begins we see him as a cool and detached man, looking for revenge and (illegal) profit.

The story is set in the period after the Civil War, in one of the Frontier settlements, far from the reach of formal institutions and refinements of civilization, which accounts for the excessive use of violence. Django is a hero who uses violence because his surroundings force him to: it is the only way to stay alive. Although his primary motivation is vengeance for the brutal death of his beloved and a monetary reward, he also uses violence to protect those who are abused. He stands up to Major Jackson's white supremacists as well as Mexican and American women-abusers and criminals. The brutal scenes of beatings, floggings and mutilations serve the purpose of accentuating the brutality and inherent violence of the lawless Frontier society that condones racism and sexism. Django's morality may be questionable, but his cause is still a noble one, and that is why he gets his prize - a beautiful girl in the end.

One conspicuous trait in the representation of Django's character is his association with excessive masculinity. Starting from a ridiculously large gun that he carries around with him and uses to kill more than forty people at once, up to his seemingly calm and 
cool nature, Django is a prototype of a western hero and a macho ideal. He is good-looking, white, and skillful with guns, strong, fearless, yet cool, quiet, mysterious and unfathomable. In other words, he exhibits all traits commonly associated with violent masculinity as explained earlier, using violence to establish control in a chaotic surrounding and to position himself as a dominant figure. The development of the Django character as a violent macho anti-hero of questionable morality and his extreme popularity with diverse audiences paved the way for other similar characters and variations establishing violence as one of the key traits associated with masculinity.

\subsection{A prototype of a "Black Hero": Shaft}

As previously mentioned, Parks's movie from 1971 provided an iconic figure of a black hero detective who fights against the corrupted system and manages to win on his own. The movie belongs to the Blaxploitation period and, in accordance with the typical mode of that era, features a powerful black character modeled on the heavily exaggerated images of white masculinity and stereotypes of African Americans (Tasker 2002: 37-9). Furthermore, both versions of Shaft belong to the genre of police and crime drama, which belongs to the domain of masculine genres due to its focus, themes, protagonists and dominant values and ideologies (Feasey 2008: 80).

One particularly important contribution of this movie is that it created an unforgettable character of a cool "Black Hero with an attitude". Parks's Shaft is a PI, a character who sides neither with the police nor with the criminals but is respected and consulted by both sides, although he trusts no-one, and neither side is able to completely trust him. Similar to Corbucci's Django, his position is that of an outsider, someone who is on the margins of the system: he is "licensed by the State", this is repeated several times in the movie, but he is also the one whom the criminal boss hires to track his kidnapped daughter. Shaft's disregard for any kind of authority or imposition is especially emphasized in several "sassy" and impertinent replies to the police officers ("What did you get? - I got laid, what did you get?"), which serve the purpose of building a character of a "cool" rebel who defies authority.

The setting is an urban one and Shaft is represented as more than able to fit in and deal with racial prejudice that he inevitably encounters. The element of racial inequality is ever present in the movie, without being overstated. For example, in one scene a taxi refuses to stop for Shaft but picks up a white passenger instead. In another scene, the police lieutenant of Italian origin tells Shaft: "You ain't so black", while comparing him to a black pen, Shaft replies comparing him to a white cup: "You ain't so white, either". The implication is that they both belong to minority groups and are perceived as different (ergo, inferior to) from the dominant WASP majority. Shaft is also referred to as "the black spade detective", with a word "spade" used in a derogatory manner. However, it is important to mention that, unlike some of the more typical earlier portrayals of African Americans, Shaft is not a criminal - his business is conducted according to the U.S. laws.

Even though there are several scenes of fights in the movie, especially the ending scene, the element of violence, inherent to the "Black Buck" stereotype, is understated in the movie. Shaft collaborates with a group of obviously militant members of the radical movement for the rights of African Americans, and criminal activities of the Harlem mafia are also mentioned. However, Shaft manages to steer clear of both militant and criminal waters - his position is rather that of a cool, detached, "stand-up guy", and the emphasis is on his love of sensual pleasures rather than a violent nature. Another element of the "Black 
Buck" stereotype is emphasized in the portrayal of Shaft: his unbridled sexuality and sexual prowess. From the opening theme, the obvious allusion of his last name, a graphic sex scene which opens the movie and numerous allusions to his sexual escapades, Shaft is portrayed as a "sex machine". He is good-looking, elegant, charming, smart, cunning, brave and virile. This is in line with what was previously said about the hypersexuality as one of the key features of the representations of black masculinity. However, in this movie, the features ascribed to the stereotypical "Black Buck" are exaggerated on purpose and represented as desirable. This strategy of trans-coding enabled subversion of the stereotype and opened the space for different portrayals of African Americans.

\subsection{Shaft 2000: "too black for the uniform, too blue for the brothers"}

A newer version of Shaft was filmed thirty years after the original (the idea was to make a sequel to the 1971 version, with the original Shaft, Richard Roundtree in the role of the 1990's Shaft's uncle); consequently, the movie reflects some of the cultural changes that happened in the USA in that period (Henry 2004: 121). First of all, Shaft is a member of the police force who willingly decides to quit and pursue the investigation on his own. We find out that he is an exemplary detective, recognized and appreciated by his colleagues. However, early in the movie, we also find out that in order to protect justice, Shaft needs to resort to violence: ironically, the only way to protect the law is to ignore it. A very important question that the move raises is that of "justifiable vigilantism" (Ibid., p. 125), i.e. the necessary use of violence in order to do the morally right thing. Violence seems to be the only viable response to the brutality of the surroundings and the only means by which the main hero can perform his heroic duties. Just like the early Shaft, or even Django, who are forced to resort to commit morally and legally dubious acts in order to protect the innocent, Shaft also needs to go outside the bounds of law to perform his duty towards fellow humans. Another change in representation is the understatement of Shaft's sexual nature. Even though there are several references and puns, the later version of this character is positioned more like a protector of women (throughout the movie he helps women and children who are victims of physical abuse) than as a sexual predator. We can see that the "Black Buck" stereotype is almost completely deconstructed, leaving only the desirable qualities in the portrayal of Shaft.

This movie also touches upon the issue of racial inequality more explicitly: it opens with an image of a beaten, half-dead male black body. Later we find out that the character who committed a crime is a wealthy white young man, Walter Wade Jr., a declared racist and a white supremacist, whereas the victim is a young, well-mannered African American student called Trey. Trey's fate is sealed when he decides to openly challenge Wade about his racist slurs and provocations by alluding to the KKK practices. The verbal abuse that the victim suffers, prequels the act of graphic violence and can be interpreted as leading directly to it. An inference can be made that deeply-embedded prejudices translated into verbal abuse are a direct cause of physical violence. Significantly, the majority of the characters present during the scene between Wade and Trey obviously condemn Wade's racist behavior but no-one reacts. The official authorities react, or rather, fail to react, in a similar manner, which is why Shaft decides to quit his job as a police detective although he still receives help and support from his colleagues on the police force. Unlike the Blaxploitation movies in which an entire white society was a metaphor for the "bad guys", the oppressive and unjust system that can only be prevailed upon by extraordinary individual effort, in the newer Shaft, it is the 
prejudiced minority and the inefficient justice system that the main hero is facing. Walter Wade Jr.'s actions are condemned both by the society and the official institutions - the irony is that the moment he is brought to justice, the system is prevented from delivering the punishment. The movie ends with a scene of ultimate violence - a murder committed by a black woman, the mother of the victim. The significance of this act is manifold: firstly, it underscores the motif of personal vendetta that is present throughout the movie; secondly, it undermines the stereotype of a violent black male by reversing the prescribed gender roles, thus suggesting that violence is not strictly gender-limited, nor, by proxy, race-bound. By suggesting that anyone - from the white supremacist to the victimized black woman, can commit violence, the movie undermines previously-mentioned techniques of associating (any) masculinity or race with violence.

The main hero, albeit impressive in his dedication and pursuit of justice, still remains impotent to stop the revenge of the victim's mother and consciously, and not because he is forced to, chooses to remain outside the police force, still helping those in need of protection. His status of a lone vigilante resembles well-known characters of cowboys and gunmen in American westerns, and may be interpreted as an announcement of a new type of a black hero: a fusion of the subverted old stereotype of male African Americans with a popular (white) macho hero.

\subsection{Django Unchained - challenging conventions}

Quentin Tarantino is often said to represent "a genre unto himself", and his movies are usually postmodern experiments with genre, history, narrative conventions, dialogue and structures (White 2010: 392-399). His remake of Django from 2012 is particularly significant because it uses stereotypes and Hollywood conventions in order to subvert them and give them new meanings (Carr 2016: 38), i.e. trans-codes them. The movie also references the three previously-discussed movies, by casting Franco Nero, the actor from the original Django, for a minor role, naming the main heroine Broomhilda von Shaft, casting Samuel L. Jackson, Shaft from the 2000 version, and using the spaghetti western setting and formula as well as the music score from Django 1966.

Django Unchained is also a story about a hero on a quest for revenge and a beloved lady, except that in the 2012 version, the hero is black. From the very beginning, a racial dimension of the movie is introduced. Similarly to newer Shaft, the opening scene shows an image of chained, whipped, scarred and enslaved black bodies, thus highlighting one of the major themes in the movie. In comparison with the original version, a major twist is the fact that the movie is set in the antebellum period of the American South, when African Americans represented subordinate minority in social terms, though not a numerical one.

The movie ridicules and subverts many of the racist beliefs of Southern slave-owners by mocking and exposing their fallacies. From the ridiculous and futile efforts of the KKK members, over the abuse of Bible and the practices of Mandingo fights, to the pseudoscientific "evidence" of phrenology, every stereotype of white superiority and black inferiority is subverted from within and made to work against itself. For example, when Master Candie refers to Django as "the exceptional nigger", he voices the racist ideology which presupposes mental inferiority of African Americans, so that every example of intelligent behavior is merely an exception that confirms the rule. However, by the end of the movie, Django is the one who outsmarts everyone else, wins and takes Candie's clothes and his pipe, symbols of his patriarchal authority. Another example of subverted stereotypes is the character of 
Stephen, the loyal servant. This character is based on the stereotype of "the Tom", a faithful servant who condones everything his master does and is ready to protect him at all costs - this is why Django mockingly calls him "Snowball". Casting Samuel L. Jackson for the role of "Snowball", an actor who not only played Shaft in the remake but also achieved his stellar status playing aggressive, cool African Americans "with an attitude" is a purposefully ironic and subversive act on the director's part. Furthermore, as the movie progresses, we find out that, although merely a servant, Stephen is the one who is consulted when making all the major decisions on the "Candieland" plantation - he is the one who effectively runs the estate and not a mere two-dimensional cardboard cut-out of a character.

When Dr. Schultz takes Django on a bounty hunting mission, one of the first things that he teaches Django is to "never break [the] character" of the valet that he is supposed to play. Playing a character is one of the key notions in the movie, and it has to do with the mimicry that African Americans had to resort to in the world that was hostile towards them and towards any idea of equality. Playing a character also has to do with stereotypical representations of African Americans in popular culture - performing the role imposed by the dominant society. When Django first appears as the character of a valet in the clothes that he picked, he looks ridiculous and out of place. The suggestion is that the prescribed role does not suit his personality, i.e. the imposed image is discordant with the reality. As the movie progresses, it becomes obvious that Django is more suitable for the main hero than for the servant, which is a powerful counter-argument against racist prejudices.

This movie also abounds in scenes of graphic violence, committed by almost everyone. Django is represented as a masculine vigilante, but his vengefulness is justifiable because he does what he does to save his life and his beloved. Violence and bloody shoot-outs are somewhat of a standard in Tarantino's movies, and this movie is no exception. Django Unchained is also a remake of the spaghetti western, so it contains violence on the account of the genre conventions. However, it still seems that scenes of violence are exaggerated. One reason for this may be to illustrate the injustice and inhumanity of racist ideology and the slave-owning system. Another may be that the unmotivated and pointless violence that most of other characters commit somehow mitigates and justifies Django's violence. He cannot be condemned because it seems that the only possible answer to the world around him is to mirror the violent behavior of others.

In the end, he is the one who symbolically burns down the plantation -the remnants of the old system, gets the girl and the prize and rides off into the sunset just like the Wild West cowboys popularized by Hollywood and popular culture. It can be said that Tarantino's Django represents a fusion between the Blaxploitation idea of black masculinity, the black "superspade" and a white hero. The fact that he gains a status of a full-fledged hero who takes the place of a common stereotype is particularly important and imbued with symbolism. By effectively showing that black Django can be as popular, as cool, as smart and, ultimately, as rich as the white one, the convention is undermined and subverted.

\section{CONCLUDING REMARKS: SHAFT AND DJANGO: A NEW WAY?}

If we were to make a final comparison of the four discussed movies, several conclusions can be drawn. Firstly, all four movies feature male protagonists who have the image of heroes or anti-heroes with highly emphasized masculinity. Secondly, in all four movies, the representation of masculinity of the heroes is connected to the excessive use of violence and 
macho behavior. The older versions of Django and Shaft both exhibit hypermasculinity and virility as their traits, whereas the newer versions seem to underplay that element and represent heroes as more romanticized versions of heroes - protectors of the weak.

Another distinctive feature of the characters discussed is their use of violence as a way of establishing their own authority, of ascertaining their own relative position and subjectivity in the (fictional) world that looks down on them and tries to curtail their freedom and individuality. Violence in these movies is used to illustrate the brutality of the respective worlds in which these characters have to be able to function. As Corbucci's Django and Singleton's Shaft illustrate, violence is not strictly limited to a particular gender or race. The discussed characters do not have much choice - it is necessary for them to use violence as a response to the corrupted system in order to protect the weak and establish justice, which makes their actions justifiable.

When it comes to the changes in the representation of African Americans and the development of the "Black Hero" character on the grounds of the "Black Buck" stereotype, a significant shift can be observed. There has been a long road from Corbucci's white Django to Tarantino's black version of the iconic hero and an even longer one from Gus in The Birth of a Nation to a modern black Django. Blaxploitation movies represent an important landmark in this process because they introduced the possibility of a black hero who confronts and defeats the corrupted system. In addition, the relative positions of the main heroes in the society also shift in these movies - from virtual invisibility, the status of an outsider, towards the most prominent position at the top of the hierarchy without (white) supervision or containment.

\section{REFERENCES}

Aldous, S., (2015), The world of Shaft, Jefferson, North Carolina: Macfarland \& Company, Inc., Publishers.

Bogle, D., (2016), Toms, Coons, Mulattoes, Mammies, and Bucks: An Interpretive History of Blacks in American Films, $5^{\text {th }}$ Ed. London: Bloomsbury Academic.

Carr, J., (2016), “Django Unchained - Disrupting Classical Hollywood Historical Realism?”, Black Camera, Vol. 7, No. 2, Spring, pp. 37-44.

Costera Meijer, I. and Van Zoonen, L., (2002), "From Britney Spears to Erasmus: women, men and representation", In Briggs, A. and Cobley, P. (Eds.) The Media: An Introduction, Harlow: Longman, pp. 326-340.

Django, (1966), Corbucci, S. (Dir.), B.R.C. Produzione Film - Roma, Tecisa - Madrid, DVD, Motion picture.

Django Unchained, (2012), Tarantino, Q. (Dir.), Weinstein Company, Columbia Pictures, DVD, Motion Picture.

Feasey, R., (2008), Masculinity and Popular Television, Edinburgh: Edinburgh University Press.

Fredrickson, G., (1987), The Black Image in the White Mind, Hanover, NH: Wesleayan University Press.

Guerrero, E., (1993), Framing Blackness: The African American Image in Film. Philadelphia, USA: Temple University Press

Hall, S., (1997), "The Spectacle of the 'Other"', In Hall, S. (Ed.) Representation, London: Sage Publications, pp. 223-290.

Henry, M., (2004), "He Is a 'Bad Mother *\$\%@!\#': Shaft and Contemporary Black Masculinity", African American Review 38, Spring, pp. 114-119.

Hughes, H., (2004), Once Upon a Time in the Italian West: The Filmgoers' Guide to Spaghetti Westerns, London: I.B.Tauris \& Co Ltd.

hooks, b., (1992), Black looks: race and representation, Boston, MA: South End Press.

hooks, b., (2004), We real cool: Black men and masculinity, New York, NY: Routledge.

Katz, J., (2011), "Advertising and the Construction of Violent White Masculinity: From BMWs to Bud Light", In Dines, G. and Humez, J. (Eds.), Gender, Race and Class in Media: a critical reader. (SECOND EDITION), Thousand Oaks, CA: Sage, pp. 261-269.

Lemelle, A. J., (2010), Black Masculinity and Sexual Politics. New York: Routledge. 
Nixon, S., (1997), “Exhibiting Masculinity”, In Hall, S. (Ed.) Representation, London: Sage Publications, pp. 291-336.

Novotny, L., (2008), Blaxploitation Films of the 1970s: Blackness and Genre, NY \& London: Taylor \& Francis e-Library, e-book.

Shaft, (1971), Parks, G. (Dir.), MGM, DVD, Motion picture.

Shaft, (2000), Singleton, J. (Dir.), Paramount Pictures, DVD, Motion picture.

Storey, J. (2012), Cultural Theory and Popular Culture. An Introduction, Harlow, England: Pearson Education Limited.

Tasker, Y., (2002), Spectacular Bodies: Gender, Genre and the Action Cinema, NY \& London: Taylor \& Francis e-Library, e-book.

White, G., (2010), "Quentin Tarantino", In Tasker, Y. (Ed.) Fifty Contemporary Directors, NY \& London: Taylor \& Francis e-Library, e-book, pp. 392-9.

\section{OD STEREOTIPA „CRNOG MUŽJAKA“ DO „CRNOG HEROJA“: PREDSTAVE O AFROAMERIKANCIMA I NJIHOVOM MASKULINITETU U AMERIČKOM FILMU}

Glavni cilj ovog rada je da se ispitaju načini predstavljanja maskuliniteta i Afroamerikanaca u četiri popularna holivudska filma. U prvom delu rada predstavljaju se osnovni teorijski i analitički pojmovi, pozivajući se na relevantnu literaturu iz oblasti studija kulture, filma i medija, Afroameričkih studija i crnog feminizma. Posebna pažnja posvećuje se prelasku sa stereotipa „Crnog mužjaka“, poznate predstave o crnom osvetoljubivom siledžiji jako izražene seksualnosti, ka liku „Crnog heroja“, nastalom 1970-ih u periodu poznatom kao Blaxploitation, koji se dalje razvijao i u skorašnjem periodu. Četiri filma koja se analiziraju su špageti vestern Serđa Korbučija iz 1966. - Đango, Saft Gordona Parksa iz 1971., i njihove moderne adaptacije, Šaft iz 2000. reditelja Džona Singltona i Đangova osveta Kventina Tarantina iz 2012. Jedan od glavnih zadataka istraživanja je prikazivanje i analiza načina na koji je poznati stereotip crnog siledžije dekonstruisan i izmenjen u filmovima skorije produkcije, te kako je uveden lik „Crnog heroja“.

Ključne reči: Afro-američke studije, maskulinitet, studije filma, predstavljanje, stereotip 